\title{
KHAT AND ISLAMIC LEGAL PERSPECTIVES: ISSUES FOR CONSIDERATION ${ }^{1}$
}

\author{
Heather Douglas and Abdi Hersi
}

\section{Introduction}

The leaves of the Khat (or Catha Edulis) plant are chewed for their stimulatory effect $^{2}$ by many people who live around the Red Sea, especially in Somalia, Djibouti and Yemen. ${ }^{3}$ As people from countries where khat is commonly used have migrated throughout the world, they have brought with them the practice of chewing khat. This migration has required many countries to address the question of whether khat should be regulated, and if so, how. In Australia the debate about appropriate regulatory approaches to khat is just beginning (Douglas and Pedder, 2010). In contrast, in countries such as the United Kingdom and Canada the question of how to regulate khat has been a contested issue for some time (Sykes et

\footnotetext{
1 This research was supported by a grant from the National Drug Law Enforcement Research Fund.

2 The khat plant contains several active constituents, including cathinone and cathine. Cathinone is the most potent constituent contained in the plant and possesses a chemical structure very similar to amphetamine. Cathinone is responsible for much of the stimulant effect of khat. The young leaves and leaf tips, which are preferred for chewing, are understood to contain higher proportions of cathinone (Graziani, Milella and Nencini 2008: 762).

${ }^{3}$ Khat is also chewed in Eastern African countries including Rwanda, Tanzania, Uganda, Kenya and Madagascar (WHO 2006).
}

${ }^{\circledR}$ Heather Douglas and Abdi Hersi 2010. 
al 2010; Klein and Metaal 2010: 586). To date studies of khat have tended to focus on the health effects of chewing the plant on individuals (Elmi 1983; Al-Hebshi and Skaug 2005; Gebissa 2004; Armstrong, 2008) and the economic effects on communities that consume, trade and cultivate the plant (Tefera 2009). While impacts on health and the economy are clearly important considerations in determining appropriate legal regulation, we argue here that because khat use is mainly associated with Muslim people (Armstrong 2008: 632), the Islamic law about khat is also an important consideration in this debate. The question of whether the use of khat is lawful pursuant to Islamic shari'a has attracted little attention from academics, researchers and policy makers. With the exception of several internet blogs (eg. Sunni Forum 2010) and Islamic websites (e.g. University Sains Islam Malaysia 2010) that provide a decree about the legality of khat according to Islamic shari'a, there is little exploration of the use of khat from the perspective of Islam. In response to this perceived gap in the literature this article explores the position of khat pursuant to Islamic law. Relevant passages from the Qu'ran and prophetical traditions are considered along with other sources of Islamic shari'a. In 2010 we conducted focus groups with Somali people who had settled in Australia and a number of participants commented directly on the relationship between their understanding of the Islamic position on khat and their decision to chew the plant. In many cases it was participants' interpretation of unofficial, or Islamic law, rather than State law that guided their decision to chew khat. The participants' views are also considered in this discussion.

We argue that an appreciation of the debates taking place between Islamic scholars, and within those communities that use khat, is important in the development of regulatory frameworks regarding khat in Australia and other Western states where khat regulation is controversial. This article begins with a general consideration of the role of Islam in regulating khat in Common Law countries such as Australia before setting out the methodological approach in relation to the focus group data collected. The article then goes on to explore the three main Islamic legal positions that have been claimed in relation to khat. We conclude with some suggestions for the way forward.

\section{Regulating khat}

Although Australia is generally considered to be a secular state (Hudson 2003: 425) the consideration of religion can and should make an important contribution to public debate (Audi 1989: 278-279). Indeed there may be risks in excluding 


\section{KHAT AND ISLAMIC LEGAL PERSPECTIVES}

Heather Douglas and Abdi Hersi

religious considerations from such discussions. In particular Maddox (2006: 309) suggests that excluding religion from debate may strengthen its power or result in alienation fostering extremism (see also Davies 2009: 76). Hudson suggests that Australian citizenship has 'religious features' and that multicultural countries like Australia should consider themselves multi-faith rather than secular (2003: 429). In a sense the Australian Constitution reflects this position when it exhorts that "the Commonwealth may not make any law ... for prohibiting the free exercise of any religion ..." (Australian Constitution 1900: section 116). If we consider Australia as multi-faith, this view has implications for the consideration of legal issues (Hudson 2003: 429). In the context of regulating khat, particular considerations may include whether khat should be prohibited, and culpability and sentencing questions (Douglas and Pedder 2010: 300). Religion generally, and Islam specifically, is arguably a feature of Australian citizenship. In Australia 74 percent of people report a religious affiliation and approximately two percent of the population identify as Muslim and this number is steadily increasing (ABS 2004).

Islam may be described as a system of law that co-exists with state law in common law countries; generally it is considered to be a form of unofficial law (Griffiths 1986). Drawing on Davies' discussion of legal pluralism we can say that Islamic law presents an 'alternative sphere of normative ordering' that 'exists alongside legal regulation' (2008: 287; see also Moore 1973). Many scholars accept that the power of law is not limited to a single site; rather it is located in multiple sites and may include alternative practices of law (Davies 2008: 286). In the Australian context, it has been argued that legal pluralism is already a reality and that shari'a operates as a form of unofficial law and non-state legal ordering (Black 2008: 214). Scholars of Islam, and those who follow Islam, disagree as to the extent to which shari'a must be followed in non-Muslim countries (Abou El Fadl 1994: 151153). As a result, in Australia, and other common law countries where khat chewing is predominantly associated with Muslim communities, Islamic law may provide an authoritative statement governing a person's decision to chew, despite existing state law (Klein 2008: 830).

In Christian communities the view of khat is not absolutely consistent. Khat is tolerated in certain circles of African Christian communities while in others it is perceived to be an ungodly and unholy plant. For example, in Kenya, Meru people who are Christian, are known to chew khat (Anderson and Carrier 2009) while some Ethiopian Christian Orthodox communities have referred to the plant as cursed, "relating that when God came to Earth all the plants bowed before him showing their ultimate reverence. The exception was khat: a plant which stood 
straight with a posture of disrespect. Then God cursed - forever you be chewed by humans" (Anderson et al 2007: 2). In East African nations where Christianity is the principal religion, for example Kenya and Uganda, the consumption of Khat is anecdotally believed to be higher in the provinces and regions where Muslims are a majority of the population. While some Yemeni Jews and Ethiopian Christians use Khat (Gebissa 2008: 83), the practice in Yemen and Ethiopia is generally associated with Muslims (Varisco 1986: 3). Gebissa reports that in Ethiopian orthodox Christian communities, khat chewing is seen to be a sign of conversion to the Muslim faith (Gebissa 2004: 52). In Ethiopia, the proportion of Christians and Muslims is fairly even, and in 2009 it was reported that it was mainly Muslim people who used khat in that country (Lamina and Babu 2009: 53). The association between Muslims and khat consumption is also emphasised by Anderson and others who observe that khat has played a symbolic function to distinguish Christianity from Islamic powers (Anderson et al 2007: 2).

Thus there is a strong association between Muslims and the consumption of khat and it is reported that Muslims are the major consumers of khat worldwide (Armstong 2008: 632). Predominantly Muslim nations such as Yemen, Somalia, and Djibouti are identified as nations where the consumption of Khat is particularly prevalent (Armstrong 2008). In these countries over 90 percent of the population identifies as Muslim (Pew Forum on Religion and Public Life 2010). Similarly in the diaspora communities of immigrants from East African and Horn of Africa communities in Australia, the United Kingdom, Canada and the United States, khat chewing is associated with Muslim people (Stevenson et al 1996: 75-77). In Australia khat chewing has been strongly associated with the Somali community most of whom are Muslim (Fitzgerald and Lawrence 2009: 4).

There is an increasing Muslim migrant population from the countries of the East African and Horn of Africa regions to common law countries including Australia, Canada, the United Kingdom and the United States (United States Department of Homeland Security 2009: 14; Australian Bureau of Statistics 2004). Some suggest that khat utilisation is central to the lives of many members of these immigrant communities including those in the United States (Armstrong 2008: 631). However, there are uncertainties about the Islamic legal perspective on khat and its significance to the increasing number of new immigrants to Australia (Fitzgerald and Lawrence 2009: 10). In order to consider the role of Islam in the Somali diaspora community in Australia we undertook a number of focus groups. The methodology we used in our study is discussed in the next section of this article. 


\section{KHAT AND ISLAMIC LEGAL PERSPECTIVES}

Heather Douglas and Abdi Hersi

\section{Methodology}

Over the course of 2010 the researchers carried out nineteen focus groups with men and women of Somali background in four Australian states: Queensland, New South Wales, Western Australia and Victoria. A key advantage of focus groups is that participants are encouraged to discuss their ideas and responses to problems and the researcher can facilitate and hear these discussions. Morgan observes that it is important that participants feel safe in expressing opinions and this will usually mean setting up a relatively homogenous group (Morgan 1998: 81, 91). There will sometimes be disagreement and participants need to feel comfortable when expressing different opinions. Thus in establishing a focus group to discuss views on controversial topics (such as khat), participants may be more comfortable expressing their views if they know the other members of the group share a particular outlook. The venue is also an important consideration, as it can have an impact on recruitment and the comfort of participants. While homogeneity of participants may help to provide a safe environment for sharing views, there are limitations implicit in this approach as well. Necessarily, responses are likely to compound certain views of the particular group. This underlines the need to carry out a number of focus groups with different types of groups to ensure a breadth of views.

Participants for this study were recruited with the assistance of relevant community cultural associations. 114 people took part in the focus groups. The mean number of participants in the focus groups was 8 participants. 89 participants were men and 35 were women. Separate groups were conducted according to two factors: gender and whether participants identified as users or non-users of khat. Despite these distinctions on some occasions 'non-users' stated in the focus groups that they did actually use khat sometimes. Interpreters in Somali were present and focus group discussions were recorded and transcribed. Themes were later extracted from the transcripts. Both interpreters and facilitators were the same gender as members of the focus group. For our research we conducted focus groups in the meeting areas used by the cultural organisations that assisted in the recruitment process and in local community meeting rooms. Most participants in the focus groups would have previously visited the spaces used so it was generally a familiar environment. A number of the participants discussed the relationship between Islam and khat. It should be noted that in New South Wales and Victoria khat use and possession is not prohibited while in Queensland and Western Australia it is illegal to possess khat (Douglas and Pedder 2010). Regardless of these differences in State law, the participants in our focus groups held divergent 
views on the Islamic position on khat and many participants referred to Islamic law rather than State law to explain why it was acceptable or unacceptable to chew the plant. The study participants' views are discussed in the following section of this article along with competing scholarly views of the Islamic position on khat.

\section{Islam and Khat}

The spirituality and status of khat varies both between Muslim groups and between individual Muslims in East Africa and the Arabian Peninsula (Rahman 1979: 223). The geographical region, culture and the sect of Islam all play a role in how individuals and groups of Muslim people perceive khat; thus because Islam "operates in distinctive ways in local contexts, there is a range of Islams" (Black 2008: 217; Al-Azmeh 1996). For example in Yemen and Uganda, where the practice of shari'a is applied mainly to matters such as marriage, divorce, inheritance, and civil issues, religious opinion generally sanctions the use of Khat (Varisco 1986: 1). In contrast, Saudi Arabia, a sovereign Arab Islamic state where a more fundamentalist Islam is practised, outlawed khat decades ago (Beckerleg 2008: 752). In Somalia the position has fluctuated regularly. There are a number of controversies and uncertainties about khat's health and financial impacts (Odenwald et al 2010) and controversies and uncertainties extend to Islamic legal rulings about the plant (Lamina 2010: 3). A community engagement forum conducted in the United Kingdom by the National Drugs and Race Equality Forum found that depending on which sheikh's teachings are followed, members of the United Kingdom Somali community may view khat use as harmless and halal (permissible) or haram (impermissible) (Buffin et al 2008: 6). Inconsistency arises in part as a result of the interpretation of the key sources of Islamic law that are used to identify guiding principles. These are, first, the Qur'an, followed by prophetical traditions known as the Sunna and Hadith (sayings and practices of the prophet Muhammed (pbuh)) then Ijma (the consensus of scholars) and Qiyas (the process of deductive analogy) (Rahman 1979; Movsesian 2010: 867). These four sources of Islamic law are accepted by Muslim scholars (Michalak and Trocki 2006: 527-534). According to Muslims, the Qur'an is the final revelation of God to humankind and Ulema (Islamic scholars) unanimously agree that it is the most authoritative guide for Muslims and the first source of the shari'a (Movsesian 2010: 867).

Across the Muslim world, opinion is sharply divided amongst Islamic scholars and Muftis on the correct approach to khat. The three main positions on khat are that it is halal (permissible), makruh (detested or discouraged) or haram (forbidden). The 


\section{KHAT AND ISLAMIC LEGAL PERSPECTIVES}

Heather Douglas and Abdi Hersi

debate between sections of the Islamic community in regard to the permissibility and impermissibility of khat is based on the inferences made in various verses in the Qu'ran and some prophetical traditions known as Hadith where they relate to intoxicants. The key to these debates lies in how the intoxicating elements that are found in the shrub khat and their impact on the human body and society at large are understood.

A well known Muslim scholar, Shatibi, argues that a balance must be struck between adherence to the texts' apparent meaning and the law giver's intention (Al Raysuni 2006: 46). It must be emphasised that the current debates on the legality of khat in the Islamic law are inherently part of the broader debate about whether or not Islamic shari'a is rigid or flexible and how far it is able to address changing social circumstances (Rahman 1979). The three main Islamic perspectives on khat are explored below. The debates about the religiosity and spirituality of Khat consumption are not constrained to the past. Many individuals within the Somali Muslim communities we spoke to used religious texts to confirm the permissibility or impermissibility of khat use in contemporary society and examples of their comments are included in the discussion below.

\section{The Halal (Lawful/Legal) Discourse on Khat}

Some argue that the deep rooted Islamic religious and cultural traditions associated with khat consumption have persisted from the fifteenth and sixteenth centuries (Anderson et al 2007: 3). Tradition was referred to by a number of the participants in our study as a justification for the halal position of khat. For example a Victorian Somali woman in our study observed: 'it has been used generation by generation ... It's been used in the Qu'ran; it's been used in religious occasions.' While in response to the question: 'Why can't you live without khat?', a Victorian Somali man commented: 'because it is our tradition, it is our way of life, we grow up with it - we enjoy it a lot. It doesn't harm us, it doesn't harm anyone.'

In the literature the khat plant has been referred to by a number of spiritual and religious terms including the 'elixir of life', 'the flower of paradise' (Anderson et al 2007: 2; Varisco 1986: 1) and 'qut ul salihin' which translates from Arabic as 'sustenance of the righteous' (Wagner 2005: 125). A well-known writer on khat, Gebissa, recounts the following words of an interviewee in one of his studies:

Khat is a tree that God loves. It's a tree blessed by Rabi (God) 
and given to us. This is a tree that man cannot command. A lot of people with power have tried to control it, especially the price of selling the leaves. None has succeeded so far. This tree is not just another ordinary plant; it is a 'Leaf of Allah'. (Gebissa (2004: 3)

Khat's existence and discovery has been linked to mysticism by some writers. For example Wagner refers to a story attributed to Yemeni people wherein the legendary prophet, Dhul Qarnayn, brought khat to Ethiopia from China in order to rid the country of pestilence and jinn (Wagner 2005: 123). ${ }^{4}$ Proponents of the halal argument claim that there are a number of spiritual rituals that are aided by the consumption of khat including reading the Qur'an and performing prayers. For example one study conducted in Ethiopia showed that 80 percent of chewers used khat to gain a good level of concentration for prayers and to facilitate contact with God (Varisco 1986: 3). Similarly, members of the Sufi sect of Islam have sometimes approved the consumption of khat for gaining concentration in relation to religious practices (Gebissa 2004: 7; Armstrong 2008: 632). A Victorian woman in our study observed: "We are 100 per cent Muslim. Yes we do Qu'ran sometimes while we eat it. We'll listen to Qu'ran you know while we chew khat but we listen to music too. So we've got both." Similarly a Western Australian man observed: "Some people use khat to get closer, to get more energy for their worship". It is claimed that khat is also an accepted part of other Muslim religious activities. For example, it has been suggested that chewing khat is a central activity during the week long Yemeni wedding celebrations (Wagner 2005: 137). Once the premise is accepted, that khat is religiously significant, it is argued by some that the continuation of Khat consumption in common law countries by Muslim immigrant groups should be tolerated as part of a commitment to multiculturalism (Armstrong 2008: 632).

Proponents of the halal position also rely on the fact that there is not a verse in the Qu'ran that explicitly mentions khat or its prohibition. It is claimed by some that the lack of specific reference to khat in the Qu'ran or the Sunna, the two most authoritative principal guides of Islamic shari'a, means that khat must be halal (Omar and Besseling 2008: 3). A male interviewee based in Queensland stated:

I don't find that [khat is not permitted] in the Qu'ran. I don't find

\footnotetext{
${ }^{4}$ Jinn are one of the three creations of Allah, like humans they have free will but less strength of will than humans (Mohammed 2004: 30).
} 


\section{KHAT AND ISLAMIC LEGAL PERSPECTIVES}

Heather Douglas and Abdi Hersi

that the Sunna has got anything to say about that... that is two things that we have to look into. To make something illegal in Islam... you either have to have it in the Hadith, or in the Sunna.

Khat is understood by many Muslims to be permissible pursuant to the Qur'an as an alternative to alcohol. While scholars generally agree that the Qur'an expressly prohibits alcohol use (Michalak and Trocki 2006: 529) no such clear prohibition exists for khat. In the Qur'an drinking alcohol, and drinking wine specifically, is identified as a disruptive social evil. One verse states:

And from the fruits of date-palms and grapes, you derive strong drink [this was before the order of the prohibition of the alcoholic drinks] and a goodly provision. Verily, therein is indeed a sign for people who have wisdom (Qur'an 16:67; Michalek and Trioci 2006: 528).

Islam has gradually implemented a four step prohibition approach to alcohol (Michalak and Trocki 2006: 527-534) and consequently, there are few disagreements about the rulings on alcohol in the Qur'an. Many of the focus group participants in our study contrasted alcohol specifically with khat. For example women in Victoria made the following comments: "It's not alcohol. It's not hashish. It's something that makes you calm and we eat with tea", and:

Facilitator: Do you drink alcohol...?

Speaker 1: No. It's against religion.

Facilitator: But khat is okay?

Speaker 2: Khat is ours.

Some of the participants specifically claimed that while alcohol is intoxicating, khat is not. For example Victorian women commented:

So drinking alcohol of course changes the whole mentality, you know the whole of thinking. You know you lose control. When you're walking ... balance is losing so that is where it's looked at, but Khat doesn't do that. So that's where it's safe... it's not a drug.

Does Khat affect someone? No. Does alcohol affect someone? Yes, because we know what they do [under the influence of 
alcohol] and they say words that they didn't want to say and they regret later on when the alcohol gets out of the body.

The question of whether khat is recognised as an 'intoxicant' by Islamic scholars is contested and is discussed further below in the section of this article relating to the haram position.

\section{The Makruh (Detested/Discouraged) Discourse on Khat.}

The claim that khat is detested and discouraged or 'makruh' reflects a risk-averse middle ground. Makruh is explained to be something which is not bad if it is consumed in moderation, but if used in excess becomes haram (Movsesian 2010: 870). Beckerleg notes that the former chief Mufti of Uganda is one of the pioneering growers of Khat and believes that khat is neither halal nor haram (Beckerleg 2006: 229). The Makruh argument with respect to khat considers khat in a similar way to tobacco smoking. Generally tobacco smoking is tolerated because of its perceived mild effect (Ghouri et al 2006: 265). Some of the participants in our study made comments that imply support for the makruh position suggesting that as long as one did not overuse khat, chewing khat is halal. Only when khat is overused or the person becomes addicted to khat does use of the plant become haram. For example two men in Queensland had the following conversation:

Speaker 1: ...if we look for addicts khat can be haram in certain jurisdictions. If you - everything you use over can affect you mentally...

Speaker 2: And if it gets overused.

Speaker 1: Yes overused has been a negative effect... Only if you expend over your [budget] for your family - so this is a habit... according to Islamic religion if you use it more than - and it affects your mental disorder then it becomes haram.

Other participants claimed that there was a relaxed position that supported individual approaches to the plant. For example another man in Queensland suggested: "some might have religious matters". Another male participant from Western Australia claimed that until there was clearer information about the impacts and effects of khat its Islamic legal status was unclear: "the main problem 


\section{KHAT AND ISLAMIC LEGAL PERSPECTIVES}

Heather Douglas and Abdi Hersi

is the people ...don't have evidence of any [disease], or any other effects, so no one can exactly straight away say this is haram, full stop". Arguably, the Makruh position is the weakest position and is probably adopted by a minority group of scholars. Some scholars argue that the Makruh position may contradict a prophetical tradition (or Hadith) that states that: 'what intoxicates in large amounts is prohibited even if taken in small amounts' (Michalak and Trocki 2006: 529). This is discussed further below.

\section{The Haram (Prohibition) Discourse on Khat}

The position that presumes khat is prohibited or haram is supported by a number of scholars of Islam. Two related arguments are relevant here. The first is that khat should be defined as an intoxicant and once it is defined in this way it must be considered haram. The second argument relies on the claim that khat should be considered haram in order to preserve human interests. In this second chain of argument it is argued that the negative effects of khat exceed its benefits and it is thus haram. These two arguments are discussed in turn below.

The term 'khamr' is used in the Qu'ran and is often translated to mean 'wine' in Arabic, however the word is understood generally to have the broader meaning of 'intoxicant' (Michalak and Trocki 2006: 528). There are a number of accepted Hadith that relate to intoxicants and they may also cover khat if khat is understood to be an intoxicant. Michalak and Trocki refer to a number of examples of relevant Hadith in this context such as: "every intoxicant is khamr and every khamr is haram' (Michalak and Trocki 2006: 529). Thus if khat is considered to be an intoxicant it is, inevitably, haram, regardless of how much is used. A Queensland man in our study commented: "There is an Islamic formula ... which means if you eat a large amount of something and [it] intoxicates you, eating small amounts of it still falls into the category of haram which means unlawful category".

Some Ulemas (Muslim scholars trained in Islamic law) apply a broad definition to the word khamr and rely on a series of prophetical traditions that focus on the necessary human interest and the concepts of 'Maqasid' or higher objectives of Islamic shari'a. These scholars reject the reliance on the text of the Qur'an and Hadith as the only sources of Islamic law. Instead, they use a mixture of sources of Islamic law to advance their case. For instance, some argue that the Qur'an is supplemented by Sunna (or practices of the prophet), but the meaning of the Sunna is determined by the Qur'an (Masud 1995: 247). The rationale is that Islamic law 
clearly stipulates that whatever clouds the mind is khamr and therefore should be regarded as harmful. In support of this position some point to various verses in the Qu'ran. For example one particular verse states that one must not perform prayers while one is intoxicated (Qur'an 4:43).

There are a number of Hadiths that are understood to supplement the Qur'anic verses about intoxicants. For example Abi Burda narrates the following:

That Abu Musa Al-Ash'ari said that the Prophet had sent him to Yemen and he asked the Prophet about certain (alcoholic) drink which used to be prepared there The Prophet said, "What are they?" Abu Musa said, "Al-Bit' and Al-Mizr?" He said, "Al-Bit is an alcoholic drink made from honey; and Al-Mizr is an alcoholic drink made from barley." The Prophet said, "All intoxicants are prohibited." (Translation of Sahih Bukhari, Book 59: Volume 5; Book 59: Number 631, available at Centre for Muslim Jewish Engagement 2011)

In the Islamic jurisprudence known as Fiqh, there are four major Madhabs, or schools of thought, in classical Sunni Islam emanating from four Imams (Movsesian 2010: 861, 870). When these four Imams were writing, Khat was not a known substance. However, these Imams discuss hashish and nutmeg and subsequently some scholars equate khat to hashish and nutmeg because of its effect on its users. Sheikh Mohamed Ibn Ibrahim has reported that all the four major Islamic schools of thought - Shafi'e, Maliki, Ahmady literally and Hanbali by deduction, agree that Nutmeg is haram (PCSR 2011). From this, his thesis argues that it is the general meaning of 'khamr' that is the key and consequently khat may be deemed to be unlawful. Accordingly, Sheikh Mohamed Ibn Ibrahim reports that unlawfulness of khat applies to its consumption and further to cultivation and supply (PCSR 2011).

The question is whether khat is defined as an intoxicant. The effects of alcohol and khat are quite different: alcohol is a depressant while the effects of khat are stimulatory. Some of the participants in our study questioned whether khat is indeed 'intoxicating', but overwhelmingly study participants also accepted that khat caused them to become 'stimulated,' 'more awake and energetic' and 'more sociable'. These experiences are consistent with pharmacological studies about the effects of khat (Graziani et al 2008: 762). A male participant from Queensland commented: 


\section{KHAT AND ISLAMIC LEGAL PERSPECTIVES}

Heather Douglas and Abdi Hersi

...because we are mostly people from the Somali community. And there is a significant number of Somali community who are ... eating or chewing the khat or also selling or buying. ...even though we are duty bound to abide by the laws of Queensland, in general the laws of Australia, but Islamically khat is not lawful because it is classified... as an intoxicant. And whatever is toxic according to the Islamic verdict it is unlawful. Therefore it should be illegal in the first place.

A male participant in Western Australia claimed that khat is addictive and observed: "It's addictive, like a drug. Drug is haram." A noted scholar on Islam, Kasule, suggests that 'intoxicants change or impair the intellect or the mind' and for that reason alone are impermissible (Kasule 2007). Clearly khat does affect the way a person responds to their surroundings and to this extent could be considered to be an intoxicant.

Some Islamic jurists and scholars have also used the concept of the 'Preservation of Necessary Human Interest' to argue that khat is haram. The necessary human interests to be preserved are determined by Muslim scholars to be the following five matters in order of importance: protection of faith, life, lineage, intellect and property (Kamali 2006: 16). Accordingly the test is that if it is the case that khat has a negative effect on any of the five necessary human interests, it then becomes haram.

Consistent with the 'Preservation of Necessary Human Interest' argument Maqasid Al Sharia, or the higher objectives of Islamic law, are also used to argue that Khat is forbidden. By using the concept of public interest (Masalih Al Mursalah), some Ulema have explored the plant's effects on health, economy and society and on the environment. For example khat crops in Yemen are negatively effecting the environment, society and the economy through the depletion of scarce water resources as a result of irrigation (Al-Mugahed 2009: 742). Similarly in Somalia khat use is recognised as a drain on the economy (Poore 2009: 135). Thus it is claimed that it is the preservation of the greater good of mankind that supports the impermissibility of khat. Social and economic effects of khat have been discussed in a number of studies (eg Sykes et al 2010) and they were also identified by a number of the participants in our study. For example a Queensland man commented that the high expenditure on khat by some users negatively affected families. He commented: "Also in the Koran ... Allah doesn't like those who are extravagant who spend their wealth unwisely. In those categories I am very 
confident to say that khat is haram which means unlawful in the first place." Similarly a New South Wales woman observed:

You could also be addicted to it, some people use less maybe on the weekend just to socialise. Some people, they can't control. Every night they buy it and use it so that means that all their income goes to khat instead of supporting their family. Or maybe even get more money out the family instead of saving for them. It's like a drug I think.

A Western Australian man accepted that Muslim scholars were divided but he observed that some scholars claim that:

...the mere fact of someone sitting for eight continuous hours and wasting the time which God almighty has given to him. Based on that alone, [scholars] will say that wasting that time on something which is not beneficial is totally un-Islamic and unlawful.

There are a number of examples of prohibition of khat by Islam in African nations. For example, most Salafi scholars in the Arabian Peninsula and other places such as Somalia consider khat use to be haram. In Saudi Arabia, the Permanent Committee for Scholarly Research and Ifta (PCSR) which comprises a group of eminent Muslim scholars has banned the leaves and buds of stimulants like khat (PCSR 2008). Similarly, the hardline Islamic Courts Union in Somalia prohibited the consumption of Khat immediately after they gained control of most of the southern part of Somalia. Furthermore, it is reported that "most conservative elements in Kenya's Muslim community argue that Mira [a type of khat] is forbidden" (Carrier 2008: 811).

\section{Conclusions}

While the Islamic position on khat is far from clear, most of those who participated in our focus groups had a strong view on the correct position pursuant to Islam and this view influenced their decision to support or reject prohibition and to chew or not to chew khat. This supports the claim that legal pluralism is a reality in Australia (Black 2008). For many Somali people living in Australia there are two laws that have influence in their lives. While the Islamic legal perspectives on khat discussed here are not consistent, they add an important dimension to the 


\section{KHAT AND ISLAMIC LEGAL PERSPECTIVES}

Heather Douglas and Abdi Hersi

general debates about the stimulant leaf and should not be ignored. In countries like Australia that purport to allow the free exercise of religion, prohibition of khat use may have implications to this freedom for some individuals. If khat is seen by some Muslims as an accepted part of cultural life and Muslim religious activity, targeting khat may then be seen as targeting these communities (Armstrong 2008: 641). In those states where khat is already prohibited a consideration of the background and motivation of those charged with khat related offences may be important to an understanding of culpability and in deciding on an appropriate sentence (Renteln and Valladares 2009: 201). Given that the overwhelming majority of khat users in Australia, and other common law states, are Muslim immigrants, the uncertain status of khat in Islam poses significant challenges to policy makers in immigrant receiving nations. As these communities' cultural norms are, to a large extent, derived from the Islamic religion, any government response to the use of khat should take into consideration these religious and cultural norms. As observed earlier, there are potential risks for government authorities if they are perceived to be making a ruling on a deeply held religious matter.

\section{References}

ABOU EL FADL, Khaled

1994 'Legal Debates on Muslim Minorities: Between Rejection and Accommodation.' Journal of of Religious Ethics 22: 127-162.

ABS (AUSTRALIAN BUREAU OF STATISTICS)

2004 'Religious Affiliation and Activity.' Paper 4.102.0 Australian Social Trends, http://www.abs.gov.au/Ausstats/abs@.nsf/1020492cfcd 63696ca2568a1002477b5/fa58e975c470b73cca256e9e00296645!OpenDoc ument (viewed 7 January 2011).

AL-AZMEH, Aziz

1996 Islams and Modernities. London: Verso.

AL-HEBSHI, N. N., and N SKAUG

2005 'Khat (Catha Edulis) - An Updated Review.' Addiction Biology 10: 299307.

AL-MUGAHED, Leen

2008 'Khat Chewing in Yemen: Turning Over a New Leaf.' Bulletin of the World Health Organisation 86(10): 741-742. 
AL RAYSUNI, Amad

2006 Imam al-Shatibi's theory of higher objectives and intents of Islamic law. Kuala Lumpur: Islamic Book Trust

ANDERSON, David, and Neil CARRIER

2009 'Khat in Colonial Kenya: A History of Prohibition and Control.' Journal of African History 50: 377-397,

ANDERSON, David, Susan BECKERLEG, Degol HAILU and Axel KLEIN

2007 The Khat Controversy: Stimulating the Debate on Drugs. New York: Berg Publishers.

ARMSTRONG, Edward

2008 'Research Note. Crime, Chemicals and Culture: On the Complexity of Khat.' Journal of Drug Issues 38(2): 631-648.

AUSTRALIAN CONSTITUTION

1900 Commonwealth of Australia Constitution Act. Available at: http://www.aph.gov.au/senate/general/constitution/index.htm (accessed 2 February 2011).

BECKERLEG, Susan

2006 'What Harm? Kenyans and Ugandan Perspectives on Khat.' African Affairs 105(419): 219-241.

BLACK, Ann

2008 'Accommodating Shariah Law in Australia's legal System: Can we? Should we?' Alternative Law Journal 33(4): 214-219.

BUFFIN, Jez, Yaser MIR and Imran MIRZA

2009 'Khat: current views from the community around the UK - findings from Community engagement forums.' London: National Drugs and Race Equality Coalition.

CARRIER, Neil

2008 'Is Mira a Drug?: Categorizing Kenyan Khat.' Substance Use and Misuse 43: 803-818.

CENTRE FOR MUSLIM-JEWISH ENGAGEMENT

2011 'Compendium of Muslim Texts.' University of Southern Carolina, http://www.usc.edu/schools/college/crcc/engagement/resources/texts/mus lim/search.html (accessed 7 February 2011).

DAVIES, Margaret

2008 'Feminism and the Flat Law Theory.' Feminist Legal Studies 16: 281304.

2009 'Pluralism in law and religion.' Pp72-99 in Peter Cane, Carolyn Evans and Zoe Robinson (eds.), Law and Religion in Theoretical and Historical Context. Cambridge: Cambridge University Press. 


\section{KHAT AND ISLAMIC LEGAL PERSPECTIVES}

Heather Douglas and Abdi Hersi

DOUGLAS, Heather, and Merali PEDDER

2010 'Legal Regulation of the drug khat in Australia.' Journal of Law and Medicine 18(2): 284-301.

ELMI, Abdullahi S.

1983 'The Chewing of Khat in Somalia.' Journal of Ethnopharmacology, 8: 163-176.

FITZGERALD, John, and Louise LAWRENCE

2009 Khat: A Literature Review. Melbourne: Centre for Culture, Ethnicity and Health.

GEBISSA, Ezekiel

2004 Leaf of Allah: Khat and Agricultural Transformation in Harerge, Ethiopia 1875-1991. Oxford: James Currey Ltd.

2008 'Scourge of Life or an Economic Lifeline? Public Discourses on Khat (Catha edulis) in Ethiopia.' Substance Use and Misuse 43(6): 784-802.

GHOURI, Nazim, Mohammed ATCHA and Aziz SHEIKH

2006 'Public health: Influence of Islam on smoking among Muslims.' British Medical Journal 332: 291-294.

GRAZIANI, Manuela, Michele S. MILELLA and Paolo NENCINI

2008 'Khat Chewing from the Pharmacological Point of View: An Update.' Substance Use and Misuse 43: 762 -783.

GRIFFITHS, John

1986 'What is legal pluralism?' Journal of Legal Pluralism 24: 1-55.

HUDSON, Wayne

2003 'The Chewing of Khat in Somalia.' Australian Journal of Politics and History 49: 425-429.

KAMALI, Mohammad

2006 An Introduction to Shariah. Kuala Lumpur: Ilmiah.

KASULI, Omar Hasan

2007 'Protection, Preservation, and Promotion of the Intellect, Hifdh Al Aql.' Paper presented at Symposium on Protection of the Aql, Kulliyah of Medicine, International Islamic University Kuantan available at: KLEIN, Axel http://omarkasule-04.tripod.com/id1290.html (accessed 7 February 2011).

2008 'Khat in the Neighbourhood - Local Government Responses to Khat Use in a London Community.' Substance Use and Misuse 43: 819 -831.

KLEIN, Axel and Pien METAAL

2010 'A good chew or good riddance-How to move forward in the regulation of khat consumption.' Journal of Ethnopharmacology 132(3): 584-589.

MADDOX, Marion

2006 God Under Howard: The Rise of the Religious Right in Australian 
Politics. Crows Nest: Allen \& Unwin.

MASUD, Muhammed

1995 Shatibi's Philosophy of Islamic Law. Kula Lumpur: Islamic Book Trust.

MICHALAK, Laurence, and Karen TROCKI

2006 'Alcohol and Islam: An Overview.' Contemporary Drug Problems 33: 523-562.

MOHAMMED, Khaleel

2004 'A Muslim Perspective on Human Rights.' Humanities Social Sciences and the Law 41(2): 29-35.

MOORE, Sally Falk

1973 'Law and Social Change: The Semi-Autonomous Social Field as an Approriate Subject of Study.' Law and Society Review 7: 719-746.

MORGAN, David L.

1998 The Focus Group Guidebook, Thousand Oaks: Sage.

MOVSESIAN, Mark

2010 'Religious Legal Theory: The State of the Field.' Seton Hall Law Review 40: 861-889.

ODENWALD, Michael, Axel KLEIN and Nasir WARFA

2010 'Introduction to the Special Issue: The changing use and misuse of khat (Catha edulis) - Tradition, trade and tragedy.' Journal of Ethnopharmacology 132: 537-539.

OMAR, Ashar, and Renee BESSELING

2008 Khat: A Drug of Growing Abuse. Sweden: Bloms Trycker AB.

POORE, Brad

2009 'Somaliland: Shackled to a Failed State.' Stanford Law Review 45: 117150.

RAHMAN, Fazlur

1979 'Towards Reformulating the methodology of Islamic Law: Sheikh Yamani on "Public Interest" in Islamic Law.' Journal of International Law and Politics 219: 219-224.

LAMINA, Sikiru

2010 'Khat (Catha edulis): The Herb with Officio-Legal, Socio-Cultural and Economic Uncertainty.' South African Journal of Science 106 (3/4): 1-4.

LAMINA, Sikiru, and Subramanian M. BABU

2009 'Khat (Catha edulis): Academic, Health and Psychological Effects on “mature" Students.' African Journal of Drug \& Alcohol Studies. 8(2), 4959.

PCSR (Permanent Committee for Scholarly Research and Ifta)

2008 Permanent Committee Fatwas Kingdom of Saudi Arabia, Group 1, 


\section{KHAT AND ISLAMIC LEGAL PERSPECTIVES}

Heather Douglas and Abdi Hersi

Volume 22, Fatwa 2159.

PEW FORUM ON RELIGION AND PUBLIC LIFE

2009 Mapping the Global Muslim Population. Washington: The Pew Forum on Religion and Public Life.

RENTELN, Alison Dundes, and Rene VALLADARES,

2009 'The Importance of Culture for the Justice System.' Judicature 92(5): 194-201.

STEWART, David W., Prem N. SHANDASANI and Dennis W. ROOK

2007 Focus groups: Theory and practice' 2nd ed. Thousand Oaks: Sage.

STEVENSON Mark, John FITZGERALD and Cathy BANWELL

1996 'Chewing as a Social Act: Cultural Displacement and Khat Consumption in the East African Communities of Melbourne.' Drug and Alcohol Review 15: 73-82.

SUNNI FORUM

2010 'Hard to Find Fatwa (khat)' available at: $<$ http://www.sunniforum.com/forum/showthread.php?33366-Hard-toFind-Fatwa-(khat) $>$ (visited 30 November 2010)

TEFERA, Tesfaye Lemma

2009 'Supply response, local reality and livelihood sustainability: The Policy Dilemma of Khat (Catha Edulis) Production in Eastern Ethiopia.' International Journal of Agricultural Sustainability 7(3): 176-188.

SYKES, Wendy, Nick COLEMAN, Philly DESAI, Carola GROOM, Mohamed GURE and Radhika HOWARTH

2010 Perceptions of the Social Harms Associated with Khat Use, Research Report 44. London: United Kingdom Home Office.

UNITED STATES DEPARTMENT OF HOMELAND SECURITY

20102009 Yearbook of Immigration Statistics. Washington: Office of Immigration Statistics.

UNIVERSITY SAINS ISLAM MALAYSIA

2010 Fatwa Management System available at http://infad.usim.edu.my/modules.php?op=modload\&name = News\&file $=$ article\&sid $=10334$ (visited 30 November 2010)

VARISCO, Daniel M.

1986 'On the Meaning of Chewing of QAT (Catha Edulis) in the Yemen Arab Republic.' International Journal of Middle East Studies 18: 1-13.

WAGNER, Mark

2005 'The Debate between Coffee and Qat in Yemeni Literature.' Middle Eastern Literatures 8(2): 121-149. 


\section{JOURNAL OF LEGAL PLURALISM}

$$
2010-\text { nr. } 62
$$

WHO (WORLD HEALTH ORGANISATION)

2006 WHO Expert Committee on Drug Dependence - 34th Report WHO Technical Report Series 942-946. 
